\title{
The Presence of Dry Eye Syndrome in Patients with Fibromyalgia: A Cross-sectional Controlled Study
}

\author{
Fibromiyalji Hastalarında Kuru Göz Sendromu Varlığı: Kesitsel Kontrollü \\ Bir Çalışma
}

\author{
Nihal TEZEL ${ }^{1}$, Aysun Şanal DOĞAN ${ }^{2}$, Ebru UMAY' ${ }^{1}$, Canan GÜRDAL ${ }^{3}$, Aytül ÇAKÇI ${ }^{4}$ \\ ${ }^{1}$ Ministry of Health Ankara Diskapi Yildirim Beyazit Training and Research Hospital, Physical Medicine and Rehabilitation Clinic, Ankara \\ ${ }^{2}$ Ministry of Health Ankara Diskapi Yildirim Beyazit Training and Research Hospital, Departments of Ophthalmology Clinic, Ankara \\ ${ }^{3}$ Dünya Göz Hospital, Departments of Ophthalmology Clinic, Ankara \\ ${ }^{4}$ Ankara Losante Hospital, Physical Medicine and Rehabilitation Clinic, Ankara
}

\begin{abstract}
$\ddot{\text { Öz }}$
Amacımız birçok objektif testle fibromiyalji (FM) hastalarında kuru göz varlığını araștırmaktır. Bu çalışmaya yeni FM tanısı konmuş 20 hasta ve 20 sağlıklı kontrol dahil edildi. Her iki grup oküler yüzey hastalık indeksi (OSDI), anestezisiz Schirmer testi, meibografi, gözyaşı menisküs ölçümü, floresein gözyașı kırılma süresi (FBUT), invaziv olmayan gözyaşı kırılma süresi (NBUT) ve korneal floresan boyama testleri (CFS) ile değerlendirildi. FM hastalarında OSDI skorları anlamlı olarak yüksek, FBUT değerleri anlamlı olarak düşük ve FBUT değerleri OSDI skorları korele idi $(\mathrm{p}<0.05, \mathrm{p}=0.007)$. Diğer parametrelerde anlamlı bir fark yoktu. Bu çalışmada FM hastalarının sağlıklı kontrollerden önemli ölçüde daha fazla oküler rahatsızlığa sahip olduğu gözlenmiştir. Komorbiditelerin doktorlar tarafindan erken tanınması, fibromiyalji tedavisinde daha etkin bir başarı sağlar.
\end{abstract}

Anahtar Kelimeler: Fibromiyalji, Kuru Göz Sendromu, Okuler Yüzey Hastalık

\section{Introduction}

Fibromyalgia syndrome (FMS) is a chronic noninflammatory disease accompanied by widespread pain and many somatic symptoms that affect women more between the ages of 30-55 years (1). Its etiology is unknown, but it has been predicted that genetic, environmental, and neurologic factors may play an important role (2). The prevalence of FMS ranges from 0.66 to $10.5 \%$ for the adult population (3). In FMS, patients often present with subjective symptoms such as dry eyes and eye pain. These noninflammatory subjective symptoms have been present in the 2010 ACR fibromyalgia (FM) criteria (4).

Dry eye is an unstable tear film causing a variety of symptoms of discomfort, visual disturbance with

\begin{tabular}{ll}
\hline & ORCID No \\
Nihal TEZEL & $0000-0002-7623-7827$ \\
Aysun Şanal DOĞAN & $0000-0002-7401-8903$ \\
Ebru UMAY & $0000-0002-4137-7731$ \\
Canan GÜRDAL & $0000-0003-3017-3853$ \\
Aytül ÇAKÇI & $0000-0002-2121-9330$ \\
& \\
Başvuru Tarihi / Received: & 28.08 .2020 \\
Kabul Tarihi / Accepted : & 22.05 .2021 \\
$\begin{array}{l}\text { Adres / Correspondence : } \\
\text { Ministry of Health Ankara Diskapi Yildirim Beyazit Training and } \\
\text { Research Hospital, Physical Medicine and Rehabilitation Clinic, } \\
\text { Ankara }\end{array}$ \\
$\begin{array}{l}\text { e-posta / e-mail } \\
\text { Nihal TEZEL }\end{array}$ \\
\hline
\end{tabular}

\section{Abstract}

Our aim is to investigate the presence of dry eye in fibromyalgia (FM) patients with using a self-reported questionnaire and objective tests. This study included 20 patients who were newly diagnosed FM and 20 healthy controls. Both groups were evaluated with ocular surface disease scale (OSDI), non-anesthetized Schirmer-I test, meibography, tear meniscus assessment, fluorescein tear break time (FBUT), non-invasive tear break time (NITBUT) and corneal fluorescein staining (CFS) tests. OSDI questions were significantly higher, FBUT values were significantly lower and FBUT values were significantly correlated with OSDI in FM patients. $(p<0.05$, $\mathrm{p}=0.007$ ). There was no significant difference in other parameters. In this context, it was observed in this study that FM patients had significantly more ocular discomfort than healthy controls. Early recognition of comorbidities by physicians ensures the success of FM treatment with comorbidities.

Keywords: Dry Eye Syndrome, Fibromyalgia, Ocular Surface Disease

potential damage to the ocular surface (5). Dry eye disease (DED) is one of the most common eye diseases affecting the ocular surface. In studies, DED is associated with many systemic diseases. DED is also frequently observed in chronic pain syndromes (6). The most common cause of dry eye is an autoimmune response against tear glands (7). DED is seen with a frequency of $0.7-33.7 \%$ in the general population (8). Besides aging, gender (being a woman) is one of the most important risk factors for DED (9). DED negatively affects the quality of life like FMS (10).

Dry eye is a common disorder of the tear reduction and ocular surface inflammation that cause ocular discomfort. The inflammatory response is a process in which the $\mathrm{T}$ cell response develops with environmental and genetic factors that are effective (4).

Tear secretion is controlled by the ocular surface lacrimal gland and the interconnecting innervation (11). Pathology in any of these structures may cause eye dryness. Also, systemic or local autoimmune responses may cause tear film dysfunction and lead to corneal problems (12).

It is reported that these eye findings in FM patients are mostly due to changes in tear production. Also, it has been reported that ocular nociceptor activity and corneal nerve changes cause dry eye in FM patients (11). 
In recent studies, the coexistence of FMS and dry eye has been frequently investigated. Although some of the studies did not have found coexistence between the two diseases, in some studies, the association has been reported (12-16).

Despite the difficulties of diagnosing dry eye, many tests are used in diagnosis. Therefore, this study aimed to investigate the relationship between FMS and DED with a self-reported questionnaire and objective tests in new diagnostic FM patients.

\section{Material and Method}

The study was a cross-sectional controlled study. This study was approved by Health Sciences University Dışkapı Yıldırım Beyazıt Training and Research Hospital local ethics committee (approve date:12.06.2017, approval number:39/23). A written informed consent was obtained from each patient. The study was conducted in accordance with the principles of the Declaration of Helsinki.

This clinical trial was conducted on patients newly diagnosed with FM and healthy individuals referred to our hospital Physical Medicine and Rehabilitation and Ophthalmology Clinics between November 2017-September 2019.

The study included 20 patients newly diagnosed with FM who had not yet started medication and 20 patients who were admitted to the outpatient clinic for a routine eye examination without any additional disease to cause dry eye.

Inclusion criteria were as follows for the FM group: (i) newly diagnosed fibromyalgia according to the criteria of the 2010 American Collage of Rheumatology4 (ii) drug not used due to FM.

Exclusion criteria were as follows for FM group: (i) previous eye surgery (ii) eye drop usage (iii) oral antihistamine or anticholinergic medications usage (iv) pregnancy (v) systemic disease that may cause dry eye (vi) dry eye history(vii)contact lens usage (vii) secondary FMS (inflammatory disease such as Sjögren)

Twenty patients with FM (20 female) and twenty patients (20 female) with healthy controls were included in either the experimental group $(n=20)$ or the control group $(n=20)$. All of the patients completed the study. Only 'right eyes' findings were included in the study.

The diagnosis of dry eye was defined according to the Report of the 2017 International SubCommittee on the Definition and Classification of the Dry Eye Study (17).

Each patient filled the OSDI questionnaire, underwent a complete ophthalmological examination, including fluorescein tear break-up time (FBUT), noninvasive tear film break-up time (NITBUT), meibography, non-anesthetized Schirmer-I test, lower eyelid meibomian dysfunction, corneal fluorescein staining, and tear meniscus area.
Noninvasive tear break-up time (NITBUT) and meibography were examined using the Scheimpflugbased corneal topography (Sirius; Costruzione Strumenti Oftalmici (CSO), Florence, Italy) device. (Figure 1 and 2).

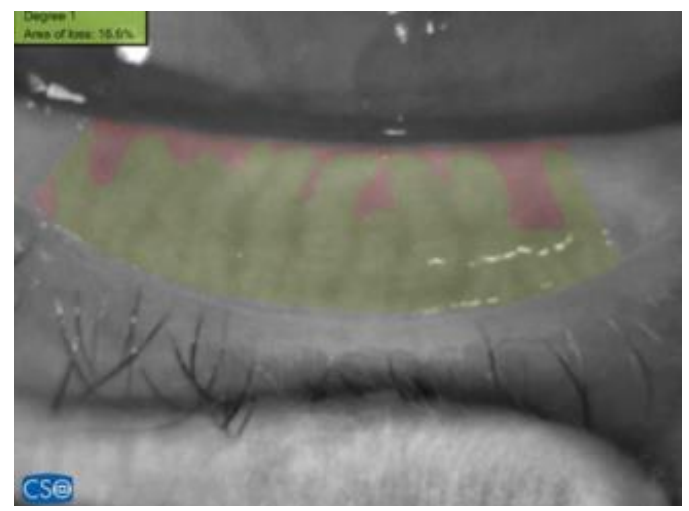

Figure 1. Meibography test

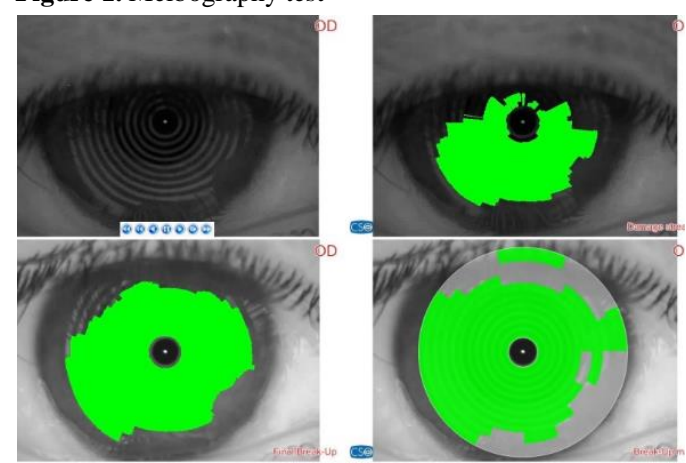

Figure 2. Noninvasive break-up time test

The overall OSDI defines the severity of dry eye in a quantitative way out of a total score of 100 (18). It includes 3 sections and 12 items that ask about symptoms, functional limitations, and environmental factors. The overall OSDI score $(0$ $100)$ defined the ocular surface as normal (012points) or as having mild (13-22 points), moderate (23-32 points), or severe (33-100 points) disease.

To obtain FBUT, a $1 \mathrm{mg}$ fluorescein sodium impregnated strip was moistened with saline and the excess liquid flicked off and placed onto the inner lateral lower eyelid margin. The patient was asked to flash 3-4 times to spread the fluorescein. Using a biomicroscope with a cobalt blue filter, the examiner measured the time from the last blink to the first appearance of a black spot on the tear film. The measurement was repeated three times and the mean value was taken. FBUT values of 10 seconds or less were included in the dry eye group.

To measure for NITBUT, the subject was positioned on a well-calibrated keratometer and three NITBUT readings were taken on the subjects' right eye only, by noting the first sign of distortion of the mires after a complete blink. NITBUT values of 17 seconds or less were included in the dry eye group. 
A non-anesthetized Schirmer-I test after five minutes $(\mathrm{mm} / 5 \mathrm{~min})$ using sterile strips was performed in all patients. Strips were placed in the lateral canthus away from the cornea and left in place for 5 minutes with the eyes closed. Readings were reported in millimeters of wetting for 5 minutes. The score less than $10 \mathrm{~mm} / 5$ minutes was considered a dry eye.

At a corneal fluorescein staining (CFS) test, staining was graded according to the Oxford scheme and the severity of meibomian gland dysfunction (MGD) was evaluated with meibograhy.

The upper and lower eyelids were gently everted and meibomian glands (MG) imaged. MG loss (MGL) was quantified by outlining its area and expressing it as a percentage of the total grading scheme.

The lower tear meniscus area was imaged simultaneously by Optical coherence tomography (OCT, RTVue-XR, Optovue Inc., Fremont, CA) (Figure 3).

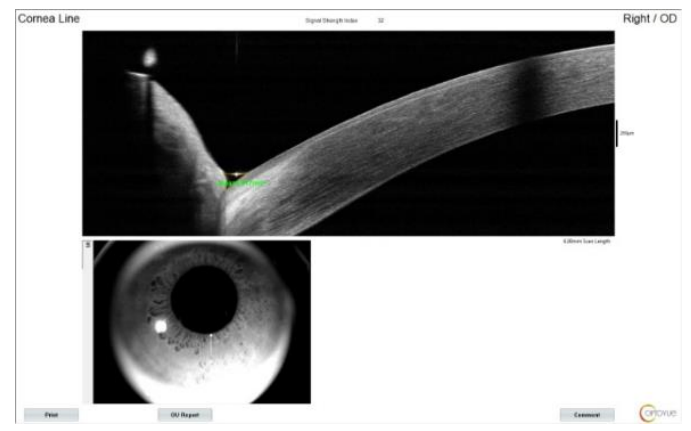

Figure 3. The lower tear meniscus area

The tests were performed on all patients. All procedures were performed by one of the authors (A.S.D). All tests were carried out on the same day. Statistical Package for the Social Sciences (SPSS 22.0 for Windows) software package was used in the analysis of the data. The continuous variables were evaluated using the Shapiro-Wilk test to determine whether or not they exhibited normal distribution. In descriptive statistics, the data were expressed as median (minimum-maximum) for continuous variables, and as frequencies and percentages (\%) for nominal variables. Statistically significant differences between the groups in terms of normal undistorted continuous variables were analyzed with the Mann-Whitney U-test. On the other hand, the significance of difference for nominal variables was analyzed using Fisher exact test. Spearman correlation coefficient was performed to measure the relationship among the evaluation parameters. A simple linear regression in univariate analysis was performed to evaluate the association between the dependent variable $(\mathrm{y}=\mathrm{OSDI})$ and the independent variable $(\mathrm{x}=$ FBUT $)$. Values of $\mathrm{p}<0.05$ were considered statistically significant.

\section{Results}

There were no significant differences in demographics between the groups $(\mathrm{p}>0.05)$ (Table $1)$.

OSDI score, dry eye severity that was evaluated according to OSDI total score and NITBUT were significantly higher in the FM group $(\mathrm{p}<0.05)$. No significant difference in TMV, FBUT, RinfMeib, CFS, and non-anesthetized Schirmer-I values were observed between the FM and the control groups. The comparison of the evaluation parameters of the patient and control groups is presented in Table 2.

Table 1. Demographic characteristics of the groups

\begin{tabular}{|c|c|c|}
\hline & FM group $(n=20)$ & Control group $(n=20)$ \\
\hline $\begin{array}{l}\text { Age } \\
\text { (years) }\end{array}$ & $\begin{array}{c}43.00 \\
(34.00-58.00)\end{array}$ & $\begin{array}{c}44.00 \\
(25.00-59.00)\end{array}$ \\
\hline \multicolumn{3}{|l|}{ Gender } \\
\hline Female & 100 & 100 \\
\hline Male & 0 & 0 \\
\hline \multicolumn{3}{|l|}{ Eye } \\
\hline Right & 100 & 100 \\
\hline Left & 0 & 0 \\
\hline
\end{tabular}

Table 2. Comparison of the FM group and the control group evaluation tests

\begin{tabular}{|c|c|c|c|}
\hline & $\begin{array}{c}\text { FM group } \\
(\mathbf{n}=20)\end{array}$ & $\begin{array}{c}\text { Control group } \\
(n=20)\end{array}$ & p \\
\hline $\begin{array}{l}\text { OSDI } \\
\text { Total score } \\
(0-100)\end{array}$ & $\begin{array}{c}34.90 \\
(12.50-50.00)\end{array}$ & $\begin{array}{c}25.00 \\
(0.0-58.40)\end{array}$ & 0.049 \\
\hline $\begin{array}{l}\text { TMV } \\
\text { (volume) } \\
\text { FBUT } \\
\text { (sn) }\end{array}$ & $\begin{array}{c}0.016 \\
(0.006-0.035) \\
10.00 \\
(5.00-12.00)\end{array}$ & $\begin{array}{c}0.017 \\
(0.005-0.033) \\
9.50 \\
(3.00-14.00)\end{array}$ & 0.287 \\
\hline $\begin{array}{l}\text { MGLA } \\
(\%) \\
\text { Schirmer } \\
(\mathrm{mm})\end{array}$ & $\begin{array}{c}14.80 \\
(5.10-32.90) \\
15.00 \\
(6.00-25.00)\end{array}$ & $\begin{array}{c}15.55 \\
(4.00-37.70) \\
12.50 \\
(5.00-30.00)\end{array}$ & 0.432 \\
\hline $\begin{array}{l}\text { Positive } \\
\text { Negative } \\
\text { NITBUT } \\
\text { (sn) }\end{array}$ & $\begin{array}{c}3(15) \\
17(85) \\
6.20 \\
(2.40-17.00)\end{array}$ & $\begin{array}{c}2(10) \\
18(90) \\
9.80 \\
(3.10-17.50)\end{array}$ & 0.049 \\
\hline $\begin{array}{l}\text { CFS: Corneal f } \\
\text { time; FM: Fibi } \\
\text { max: minimun } \\
\text { time ; OSDI: } \\
\text { volume }\end{array}$ & $\begin{array}{l}\text { cein staining; } P \\
\text { lgia; MGLA: } \\
\text { imum; NITBU } \\
\text { surface diseas }\end{array}$ & $\begin{array}{l}\text { Fluorescein te } \\
\text { mian gland loss } \\
\text { lon-invasive tea } \\
\text { lex; TMV: Tea }\end{array}$ & $\begin{array}{l}\text { ak-up } \\
\text { Min- } \\
\text { ak-up } \\
\text { iscus }\end{array}$ \\
\hline
\end{tabular}

A negative moderate correlation $(\mathrm{r}=-0.582)$ was observed between FBUT and OSDI scores in FM groups ( $\mathrm{p}=0.007)$. No correlation was found with the other parameters investigated. The correlation of OSDI scores with the other evaluation parameters are reported in Table 3.

OSDI and FBUT scores were evaluated in the simple linear regression analysis. The distribution chart of the data of the patients is shown in Figure 4, and the regression analysis results are shown in Table 4. According to the distribution chart, a negative correlation was found between OSDI scores and FBUT scores $(y=-3.064 x+15.139)$. 
Table 3. Correlation of OSDI scores with the other evaluation parameters

\begin{tabular}{lc}
\hline & OSDI $(\mathbf{r} / \mathbf{p})$ \\
\cline { 2 - 2 } FTFV & $-0.002 / 0.993$ \\
MGLA & $\mathbf{- 0 . 5 8 2 / 0 . 0 0 7}$ \\
Schirmer & $0.242 / 0.305$ \\
Rcb & $0.025 / 0.918$ \\
NITBUT & $0.141 / 0.554$ \\
TMV & $-0.423 / 0.063$ \\
CFS & $-0.002 / 0.993$ \\
\hline CFS: Corneal fluorescein staining ; FBUT: Fluorescein tear break-up \\
time; MGLA: Meibomian gland loss area; NITBUT: Non-invasive \\
tear break-up time OSDI: Oculer surface disease index; TMV:Tear \\
meniscus volume; r: correlation coefficient.
\end{tabular}

According to the regression analysis, FBUT and OSDI scores were correlated $33.8 \%$ and one unit increase in FBUT scores was predicted to 0.3064 unit decrease in OSDI scores $(\mathrm{B}=-3.064, \mathrm{p}=0.007)$.

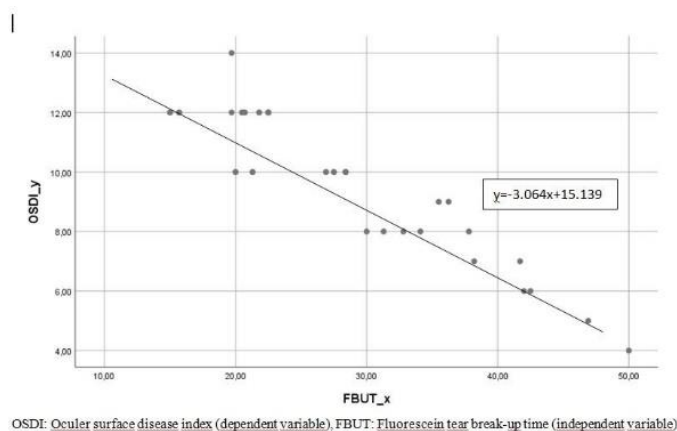

Figure 4. Scattered plots of patients' data

Table 4. Simple Linear Regression Analysis between OSDI and FBUT scores

\begin{tabular}{|c|c|c|c|c|c|}
\hline & $\mathbf{R}^{2}$ & B & SE & $\begin{array}{c}95 \% \text { CI } \\
\text { (lower-upper) } \\
\text { for B } \\
\end{array}$ & $\mathbf{p}$ \\
\hline FBUT & 0.338 & -3.064 & 1.010 & $-5.185--0.943$ & 0.007 \\
\hline
\end{tabular}

\section{Discussion}

The inflammatory process is mentioned in many literatures on FM (19). Despite the presence of inflammatory rheumatic diseases and dry eye syndrome, the presence of inflammatory mechanisms in FM etiopathogenesis is uncertain (2). Symptoms of ocular dryness coexist in a significant proportion of FM patients (16). The severity and prevalence of somatic symptoms in FMS are very effective in the treatment process. Early recognition and the treatment of these symptoms enable the disease to be controlled more easily. In this study, it was aimed to investigate the association of FM and DES using many-objective tests in patients with newly diagnosed FM.

Although it is not possible to say the presence of dry eye in FM patients with only one ophthalmological test, OSDI scores were found to be significantly higher than those of healthy patients in many studies $(11,12,15)$. In our study, unlike others, we evaluated our patients with multiple objective examination methods such as NITBUT, meibography, non-anesthetized Schirmer-I test, corneal fluorescein staining, and tear meniscus area. In our study, OSDI questions were significantly higher, FBUT values were significantly lower and FBUT values were found to be significantly associated with OSDI in FM patients. There was no significant difference in other parameters. Türkyilmaz et al. examined the relationship between FM activity and dry eye (15). They found OSDI scores in FM patients were significantly higher than those of the control group similar to our study. Contrastly, they found that non-anesthetized Schirmer-I and TBUT tests scores were found higher in the FM group. Schuster et al. evaluated FM patients with NRS-pain and non-anesthetized Schirmer-I test in terms of eye pain and dry eye (14). Similar to our study, they didn't find any difference in the non-anesthetized Schirmer-I test between the groups.

Like our study, Vehof et al. found increased severity of DED symptoms across all domains of the OSDI, even though they did not found any objective ocular surface signs (12).

Gallar et al. evaluated tear production and corneal sensitivity in FM patients. Similar to our study they found OSDI scores higher in FM patients, and in contrast to our study, non-anesthetized Schirmer-I test positivity was higher in the FM group (11). However, they did not exclude the patients who use drugs with anticholinergic effects. Thus, this can affect non-anesthetized Schirmer-I test positivity.

Similar to our study, Ulusoy et al. found TITBUT values significantly lower than those of the control group in FM patients (6). After the relationship was found between FM and neuropathic pain, studies on the relationship between the cornea that has a highly innervated structure and dry eye have intensified (20). Some studies have shown corneal surface reduction and small-fiber involvement in FM patients $(21,22)$. In a study, Turan et al. investigated the presence of corneal small fiber neuropathy in FM patients (18). Similar to our study, OSDI scores and FBUT test scores were found to be significantly higher in FM patients, and there was no difference between the two groups in the non-anesthetized Schirmer-I tests.

The presence of early subjective eye findings in FM patients compared to the controls indicates the necessity of ophthalmologic follow-up of these patients. During follow-up, examining the eye findings of FM patients may be delayed. These eye findings, which may aggregate patients' symptoms and can be overlooked in routine controls negatively affect the treatment. The OSDI score is a simple test that can be easily applicable in outpatient clinics.

FMS negatively affects the quality of life (23). Eye findings have a more negative impact on the quality of life in FM patients. Early diagnosis, precautions, and treatment can reduce the severity of 
the disease. Also, it will be appropriate to select the medication from the group with the least or no adverse effects on the eye in FM patients that have a high OSDI score.

The limitation of our study is that it is a singlecenter study, the number of patients is low and patients were not evaluated with the quality of life scale. A strength of our study is that DES is not only evaluated by the non-anesthetized Schirmer-I test but also it is confirmed by self-reported questionnaires and objective tests.

In conclusion, in our study, OSDI scores of FM patients were found to be significantly higher than those of the control group. When evaluating FM patients, eye symptoms should be questioned and patients with high OSDI scores should be directed to the relevant department. Early recognition of comorbidities by physicians ensures the success of FM treatment with comorbidities.

Ethics Committee Approval: This study was approved by Health Sciences University Dışkap1 Y1ldırım Beyazıt Training and Research Hospital local ethics committee (approve date:12.06.2017, approval number:39/23).

\section{References}

1. Bucourt E, Martaillé V, Goupille P, et al. A Comparative Study of Fibromyalgia, Rheumatoid Arthritis, Spondyloarthritis, and Sjögren's Syndrome; Impact of the Disease on Quality of Life, Psychological Adjustment, and Use of Coping Strategies. Pain med. 2019:20(2):255.

2. Bazzichi L, Giacomelli C, Consensi A, et al. One year in review 2016: fibromyalgia. Clin Exp Rheumatol. 2016;34(2):145-9

3. Cavalcante AB, Sauer JF, Chalot SD, et al. The prevalence of fibromyalgia: a literature review. Rev Bras de Reumatol. 2006;46(1):40-8

4. Wolfe F, Clauw D, Fitzcharles M, et al. The American College of Rheumatology preliminary diagnostic criteria for fibromyalgia and measurement of symptom severity. Arthritis Care Res. 2010;62(5):600-10.

5. Shimazaki J, Seika D, Saga M, et al. A prospective, randomized trial of two mucin secretogogues for the treatment of dry eye syndrome in office workers. Sci Rep. 2017;7(1):15210.
6. Ulusoy MO, Kal A. Ön Segment Optik Koherans Tomografi Kullanarak Farklı Romatolojik Hastalıklarda Kuru Göz Değerlendirmesi. MN Oftalmoloji 2017;24(4): 192-7.

7. Stern ME, Schaumburg CS, Pflugfelder SC. Dry eye as a mucosal autoimmune disease. Int Rev Immunol. 2013;32(1):19-41

8. Kırağ N. Temel AB. Yaşlı Bireylerde Kuru Göz Semptomu Sıklığı ve İliş̧kili Faktörler. Anadolu Hemş Sağ Bil Derg. 2016;19(4):243-51.

9. Utine CA. Kuru Göz Oluşum Mekanizması ve Siniflandirılması. MN Oftalmoloji. 2016;23(11):1-8

10. Uchino M, Schaumberg DA. Dry eye disease: impact on quality of life and vision. Curr Ophthalmol Rep. 2013;1(2):51-7.

11. Gallar J, Morales C, Freire V, et al. Decreased corneal sensitivity and tear production in fibromyalgia. Invest Ophthalmol Vis Sci. 2009;50(9):4129-34.

12. Vehof J, Smitt-Kamminga NS, Kozareva D, et al. Hammond Clinical Characteristics of Dry Eye Patients With Chronic Pain Syndromes. Am J Ophthalmol. 2016;162(2):59-65.

13. Karakoyun A, Yaşar E, Gürlevik U, et al. Fibromiyalji Hastalarında Göz Bulgularının Değerlendirilmesi. Turk J Osteoporos. 2019;25(1):19-22.

14. Schuster AK, Wettstein M, Gerhardt A, et al. Eye pain and dry eye in patients with fibromyalgia. Pain Med. 2018;19(12):2528-35.

15. Türkyilmaz K, Türkyilmaz AK, Kurt EE, et al. Dry eye in patients with fibromyalgia and its relevance to functional and emotional status. Cornea. 2013;32(6):862-6.

16. Chen CH, Yang TY, Lin CL, et al. Dry Eye Syndrome Risks in Patients With Fibromyalgia. Medicine. 2016;95(4):2607.

17. Shimazaki J. Definition and diagnostic criteria of dry eye disease: historical overview and future directions. Invest Ophthalmol Vis Sci. 2018;59(1):7-12.

18. Schiffman RM, Christianson MD, Jacobsen G, et al. Reliability and validity of the ocular surface disease index. Arch Ophthalmol. 2000;118(5):615-21.

19. Benlidayi IC. Role of inflammation in the pathogenesis and treatment of fibromyalgia. Rheumatol Int. 2019;39(2):78191.

20. Turan KE, Kocabeyoglu S, Unal-Cevik I, et al. Ocular surface alterations in the context of corneal in vivo confocal microscopic characteristics in patients with fibromyalgia. Cornea. 2018;37(2):205-10.

21. Üçeyler N, Zeller D, Kahn AK et al. Small fibre pathology in patients with fibromyalgia syndrome. Brain. 2013;136(6):1857-67.

22. Ramírez M, Martínez-Martínez LA, Hernández-Quintela E, et al. Small fiber neuropathy in women with fibromyalgia. An in vivo assessment using corneal confocal bio-microscopy. Semin Arthritis Rheum. 2015;45(2):214-9.

23. Hoffman DL, Dukes EM. The health status burden of people with fibromyalgia: A review of studies RFBUT ile that assessed health status with the SF-36 or the SF-12. Int J Clin Pract. 2008;62(1):115-2. 